\title{
The Influence of Blended Learning Model Based on Problems of Physical Learning Achievements by Students of Class $X$ Science in SMA 6 Denpasar Academic Year 2017/2018
}

\author{
Ni Putu Nadia Nikki Utami ${ }^{1}$, I Wayan Santyasa ${ }^{2}$, Iwan Suswandi ${ }^{3}$ \\ I,2,3Universitas Pendidikan Ganesha, Indonesia \\ Udayana Street No.I I Singaraja - Bali 81116 \\ Email:npnadianikkiu@gmail.com ${ }^{\mathrm{I}}$
}

\begin{abstract}
Learning achievement is the result achieved by someone after doing the learning process. One of the factors that influence learning achievement is the use of the learning model. This study aims to know the differences in achievement of students learning to use problem-based blended learning models and traditional blended learning. This study uses a quasi-experimental method of "non-equivalent pretest-posttest control group design." The study population is all class X IPA with a total of 6 classes or 2I0 people. The sample consists of 3 classes or 107 people. Student learning achievement data were analyzed by descriptive analysis and ANOVA one-way $(\alpha=0.05)$. The results of this study reveal that there are differences in student achievement due to the learning model. Higher learning achievement was achieved by problem-based blended learning models $(F=264.307 ; \alpha<0.05)$. The LSD test results showed that the learning achievement of students in the MBLBM group was higher than MBL, the learning achievement of the MBLBM group was higher than that of MPK, and the learning achievement of the MBLBM group was higher than that of MPK.
\end{abstract}

Keywords: problem-based blended learning model, a blended learning model, the conventional learning model, learning achievement

\section{Introduction}

Education has a critical role in realizing quality human resources. In this case, Education will function to develop the mindset of human resources to be able to contribute to determining the direction of development of a country. Quality education is the mandate of Law Number 20 of 2003 concerning the National Education System (Sisdiknas) article 50 section 2 which reads, "The government determines national policies and national education standards to ensure the quality of national education." Through this law, it is also stated that national education functions to develop the capacity and form dignified national character and civilization in order to educate the lives of the nation, aiming to develop the potential of students to become faithful and fearful people of God, noble, healthy, knowledgeable, capable, creative, independent, and a democratic and responsible citizen. Guided by the National Education System, the government has made various strategic efforts to realize the goals of national education in order to create quality education, one of which is the 2013 Curriculum development. According to Setyorini[I], 2013 Curriculum is a curriculum that prioritizes understanding, skills, character education, active in discussions and presentations, and has a high level of courtesy. 2013 curriculum in the application of science learning especially physics at all levels of education emphasizes the scientific approach which consists of observing, asking, trying, associating, and communicating. The implementation of the 2013 Curriculum to science learning, especially physics at all levels of education emphasizing the scientific approach consisting of observing, asking, trying, associating, and communicating. This strategy can prove that the 2013 curriculum following the nature of physics is to obtain the truth must be empirically through the scientific method [2]. This model is expected to have a positive influence on students' physics learning achievements and the realization of quality education in Indonesia. Concerning the realization of the efforts that have been made by the government, the quality of physics learning obtained by students in schools has a high qualification which has implications for the optimal learning achievement possessed by students.

The reality is that all efforts made by the government have not provided results that are in line with expectations. in a study on the analysis of students' physics learning outcomes at Arjasa State High School showed that physics learning outcomes were still low. Research conducted by [3], on the analysis of high school physics learning 
outcomes showed that physics learning outcomes were still very low with an average score of 56,I83. Similarly, the research conducted [4] shows that the physics learning achievement of students at SMP Negeri 2 Sawan was still very low, especially in active electrical materials. Based on these facts, it was indicated that students' physics learning achievement is still very low. One of the causes of low student achievement comes from external students. [I] which revealed that low student learning outcomes were due to the use of conventional learning models and still emphasized memorization, not discovery. Similar results were expressed by [5] improper use of methods caused the low learning outcomes. Learning methods applied in schools direct students to memorize and hoard various information and not develop students' thinking skills. Based on this opinion, it can be understood that the low achievement of students' physics learning is caused by external factors, namely the use of conventional learning models that are not following the nature of physics learning.

The development in the information and communication technology sector (ICT) is a product of the times that offer new things to the world of education as a means to support the learning process. One is a learning model that can be used to conduct learning activities outside of school by utilizing information and communication technology without eliminating face-to-face learning activities in schools and encouraging students to develop their thinking skills which will have implications for improving student learning achievement is a problem-based blended learning model. The problem-based blended learning model is a learning model that uses authentic problems as a learning stimulus by combining online and faceto-face learning approaches in class.

The research conducted by [6] revealed that blended learning models could improve student learning achievement compared to conventional learning models. The results showed that the application of blended learning that integrates faceto-face learning and e-learning is one factor in improving student learning achievement. Between students who study in the experimental group with blended learning models obtain better academic achievement scores and students in the control group who learn to use traditional learning models [7]. Blended learning models combine traditional and online-based learning models that allow students to be more flexible in managing learning time. Other studies on the application of the problem-based learning model in learning carried out by [9] revealed that the problem-based learning model is a useful learning model in improving student academic achievement including knowledge retention, conceptual understanding, and student attitudes.[9] states that the problem-based learning method can improve learning motivation critically: diligent in doing assignments, resilient in difficulties, interest in problems, happy to work independently, doing assignments regularly, and happy to find and solve problems. State that learning with blended-problem based learning has an impact on student learning activities. In another study conducted by [3] provides student learning outcomes that are learning through blended based learning problems better than students who learn through direct learning based on blended and for students who have the high and low motivation, Blended problem-based learning has a positive impact on student learning achievement. Another study conducted by [IO] revealed that problembased blended learning models are effective in improving student learning outcomes. Besides, the application of problem-based blended learning models can increase student motivation in learning.

\section{Method of Research}

This research was conducted in SMA Negeri 6 Denpasar of the second semester in the academic year 2017/2018. The instrument trial was conducted in class XI IPA in SMAN 8 Denpasar. The population of this research is all the class $\mathrm{X}$ IPA consisting of 6 classes with a total of 210 people. The sample that has been used in the study uses three classes selected by two stages of random assignment technique. The three classes in this study are class X IPA 5 as the first experimental class, class X IPA 6 as the second experimental class, and class X IPA I as the control class. The number of samples in this study was 107 students which included 36 students in the first experimental class, 36 students in the second experimental class, and 35 students in the control class.

This study uses quantitative research methods included in the experimental research. The type of research that will be carried out is quasiexperimental or quasi-experimental research. The research design used in this study was nonequivalent pretest-posttest control group design. The research design is shown in Figure I. 


\begin{tabular}{ccc}
$\mathrm{O}_{1}$ & $\mathrm{X}_{1}$ & $\mathrm{O}_{2}$ \\
\hdashline $\mathrm{O}_{3}$ & $\mathrm{X}_{2}$ & $\mathrm{O}_{4}$ \\
$-\mathrm{O}_{5}$ & $\mathrm{X}_{3}$ & $\mathrm{O}_{6}$
\end{tabular}

(Source: Santyasa, 2018)

Figure I.Research design

where:

OI: preliminary observations of students' learning achievements with blended learning models based on problems

O3: preliminary observations of students' learning achievements with blended learning models

O5: preliminary observations of students' learning achievements with conventional models

O2: The final observation of students' learning achievement with a blended learning model is problem-based

O4: final observation of students' learning achievement with blended learning models

O6: final observation of student learning achievement with conventional learning models

XI: Treatment with blended learning models is problem-based

X2: Treatment with blended learning models

X3: Treatment with direct (conventional) learning models

The instrument used in this study is a physics learning achievement test to measure students' understanding of simple material momentum, impulses, and harmonic vibrations. The test form was constructed in the form of an expanded multiple choice test consisting of 25 items based on Bloom's taxonomy as a result of the revisions of Anderson and Krathwohl. Each item has a score of 0 to 4 . All items in the instrument are valid and have Cronbach's Alfa reliability value of 0.887 .

Data collected from this study were simple physics learning achievement data for momentum and impulse material and harmonic vibration in the form of pretest and posttest. This study used two analytical techniques, namely descriptive analysis, and covariance analysis. Descriptive analysis techniques were used to describe percentages, mean values, and standard intersections. The data analysis technique used to test the hypothesis in this study was a one-way covariate analysis (ANACOVA) technique with the covariate variables being the initial physics learning achievement. Candiasa (2010) stated several assumptions that must be considered in conducting covariate analysis, namely: (I) data normal distribution, (2) variants in homogeneous groups, and (3) the presence of a linear relationship between the independent variables and the dependent variable. The following statistical hypothesis is formulated:

$\mathrm{H}_{\circ}: \mu_{1}=\mu_{2}=\mu_{3}$ :

There is no difference in students' physics learning achievement between students who learn using problem-based blended learning models, blended learning models, and conventional learning models.

$\mathrm{H}_{1}: \mu_{1} \neq \mu_{2} \neq \mu_{3}$ :

There are differences in students' physics learning achievement between students who learn using problem-based blended learning models, blended learning models, and conventional learning models.

\section{Research Results and Discussion}

The data obtained in this study are the initial learning achievement (pretest) and also student learning achievement (posttest). The data collected through the data retrieval process is then analyzed using a statistical approach. Dissemination of learning achievement data for each group is presented in Table I and Table 2, the difference between pretest and posttest mean scores of students in each group is shown in Figure 2.

Table I. Data on physics Student Average Pretest Learning Achievement for Experimental Groups and Control Groups

\begin{tabular}{ccc}
\hline Class & Learning Model & M \\
\hline X IPA I & MPK & 31,26 \\
\hline X IPA 5 & MBL & 31,36 \\
\hline X IPA 6 & MBLBM & 31,50 \\
\hline
\end{tabular}

Table 2. Data on physics Student Average Posttest Achievement for Experiment Groups and Control Groups

\begin{tabular}{ccc}
\hline \multicolumn{1}{c}{ Class } & Learning Model & M \\
\hline X IPA I & MPK & 67,40 \\
\hline X IPA 5 & MBL & 76,47 \\
\hline X IPA 6 & MBLBM & 81,25 \\
\hline
\end{tabular}

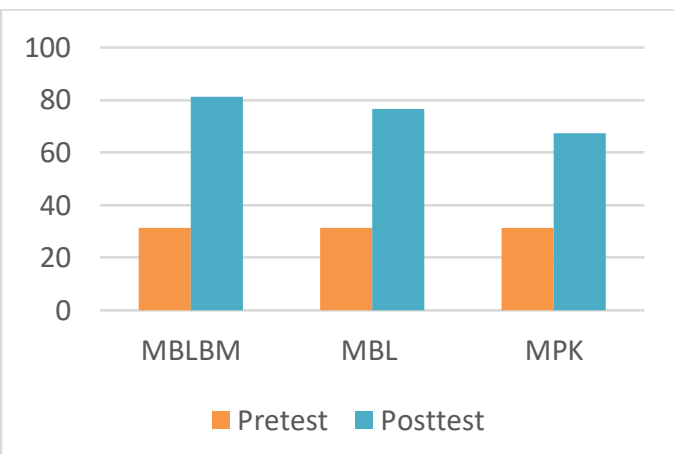

Figure 2. Disputes between students' pretest and posttest scores

\section{Hypothesis testing}

Hypothesis testing uses covariate analysis (ANAKOVA) one path with the help of a 
computer program SPSS-PC 23.0 for Windows. Calculation results are shown in Table 3.

Table 3. Results of one-way ANAKOVA Calculation

\begin{tabular}{|c|c|c|c|c|c|}
\hline Source & $\begin{array}{l}\text { Type III } \\
\text { Sum of } \\
\text { Squares }\end{array}$ & $\mathrm{df}$ & $\begin{array}{l}\text { Mean } \\
\text { Square }\end{array}$ & $\mathrm{F}$ & Sig. \\
\hline $\begin{array}{c}\text { Correc } \\
\text {-ted } \\
\text { Model }\end{array}$ & $38 \mathrm{I} 5,9 \mathrm{I} 2$ & 3 & $\begin{array}{l}\text { I27I } \\
97 \mathrm{I}\end{array}$ & $\begin{array}{c}200,09 \\
8\end{array}$ & $\begin{array}{c}0,00 \\
I\end{array}$ \\
\hline $\begin{array}{l}\text { Inter- } \\
\text { cept }\end{array}$ & 393,857 & I & 393,857 & 61,959 & $\begin{array}{c}0,00 \\
\mathrm{I}\end{array}$ \\
\hline Pretest & 3 I I,380 & $\mathrm{I}$ & $31 \mathrm{I}, 380$ & 48,984 & $\begin{array}{c}0,00 \\
\mathrm{I}\end{array}$ \\
\hline Model & 3360,250 & 2 & $\begin{array}{c}\mathrm{I} 680, \mathrm{I} 2 \\
5\end{array}$ & $\begin{array}{c}264,30 \\
7 \\
\end{array}$ & $\begin{array}{c}0,00 \\
\mathrm{I}\end{array}$ \\
\hline Error & 657,742 & $\begin{array}{c}10 \\
3 \\
\end{array}$ & 6,357 & & \\
\hline Total & $\begin{array}{c}608 \mathrm{I} 47,00 \\
0 \\
\end{array}$ & $\begin{array}{c}10 \\
7 \\
\end{array}$ & & & \\
\hline $\begin{array}{c}\text { Correc } \\
\text {-ted } \\
\text { Total } \\
\end{array}$ & 4470,654 & $\begin{array}{c}10 \\
6\end{array}$ & & & \\
\hline
\end{tabular}

Based on the summary of the results of ANAKOVA one path in Table 3 it was decided:

First, the effect of the initial physics learning achievement on the dependent variable in this study is the achievement of students' physics learning, the statistical value $F=48,984$ with the significance number 0,00I. The significant number is smaller than 0.05 . These results indicate that there is a significant effect $(p<0.05)$ between covariates on students' physics learning achievement. In other words, relevant covariance analysis is used in this study.

Second, the effect of the independent variable on the dependent variable is the student physics learning achievement obtained by the statistical value $F=264.307$ with a significant number of 0.00I. The number of significant obtained is less than 0.05 , so the decision is to reject $\mathrm{Ho}$ and to accept HI. Empirically it is proven that there are differences in students' physics learning achievement between students who learn using problem-based blended learning models, blended learning models, and conventional learning models.

In this study, further testing is needed to find out the significance of the difference between the mean one and the other mean if there is a significant difference. Follow-up covariance analysis in this study tested the significance of differences in the average score of the physics learning achievement test between groups using Least Significant Difference (LSD). Follow-up test results are presented in Table 4.
Table 4. The significance of Differences Score of Average Intergroup Learning Achievement.

\begin{tabular}{|c|c|c|c|c|}
\hline $\begin{array}{c}\text { (I) } \\
\text { Model }\end{array}$ & (J) Model & $\begin{array}{c}\boldsymbol{\mu}(\mathbf{I}) \\
-\boldsymbol{\mu}(\mathbf{J})\end{array}$ & SD & Sig. \\
\hline MBLM & MBL & 4,622 & 0,595 & $0,00 \mathrm{I}$ \\
\hline MBLM & MPK & 13,577 & 0,600 & $0,00 \mathrm{I}$ \\
\hline MBL & MBLM & $-4,622$ & 0,595 & $0,00 \mathrm{I}$ \\
\hline MBL & MPK & 8,955 & 0,599 & $0,00 \mathrm{I}$ \\
\hline MPK & MBLM & $-13,577$ & 0,599 & $0,00 \mathrm{I}$ \\
\hline MPK & MBL & $-8,955$ & 0,600 & $0,00 \mathrm{I}$ \\
\hline
\end{tabular}

Based on Table 4, the difference in average scores of students' physics learning achievement between the MBLM learning group and MBL $\Delta \mu=\mu(\mathrm{I})-\mu$ $(\mathrm{J})=4.622$ with a standard deviation of 0.595 and significance of 0.000 . The difference in average scores of physics learning achievement students between the MBLM and MPK learning groups is $\Delta \mu=\mu(\mathrm{I})-\mu(\mathrm{J})=\mathrm{I} 3,577$ with a standard deviation of 0,600 and a significance of 0,000 . The differences in the mean scores of students' physics learning achievement between MBL and MPK learning groups is $\Delta \mu=\mu(\mathrm{I})-\mu(\mathrm{J})=8,955$ with a standard deviation of 0,599 and a significance of 0,000 . The significance value obtained from each difference is smaller than 0.005 , while the value of $\Delta \mu$ obtained from each difference is higher than the LSD value of I.805. There is a significant difference in the average score of physics learning achievement between groups who study with MBLM and MBL, MBLM and MPK, as well as MBL and MPK. Physics learning achievement achieved by students who study with problembased blended learning models is higher than students who learn to use blended learning models or conventional learning models. This phenomenon shows that the learning achievement of students who take lessons with problem-based blended learning models is relatively better compared to students who take lessons with Blended learning models or conventional learning models.

This study obtained results that problem-based blended learning models were able to improve student learning achievement compared to blended learning models and conventional learning models. This result is consistent with research conducted [3] which shows that the application of problembased learning models based on blended learning (PBL-BL) has a good impact on students' physics learning outcomes compared to the direct instruction model based on blended learning (DI$\mathrm{BL})$. Also, the results of this study are supported by research conducted by $[\mathrm{IO}]$ which states that problem-based blended learning models are effectively used in improving student learning outcomes compared to conventional learning 
models. The use of problems in the learning process has been proven to have a positive impact on student learning achievement $[\mathrm{I}, 5,8]$. In addition, the application of problem-based learning models has a positive impact on knowledge retention, conceptual development, student attitudes [8] and is able to improve learning motivation with diligent criteria in the system, tenacious in difficulties, interest in problems, doing tasks regularly, and happy to find and solve problems [9].

The results of this study also found that blended learning models were able to improve student learning achievement compared to conventional learning models. This result is in line with the research conducted by [7] which found that students in the blended learning model group obtained better learning achievement compared to students in the traditional learning model group. Another study conducted by [II] revealed that the application of blended learning models has a positive impact on student learning outcomes in the form of improving learning outcomes. Besides, the use of blended learning based Schoology models results in reduced theoretical class hours in class so that it can be filled with practical work to enhance students' understanding further. Learning with blended learning models also has a positive impact on student involvement in the learning process [12].

Problem-based blended learning models and blended learning models allow the learning process to be more professional to handle learning needs in the most effective, efficient, and high-appeal way. The learning process is not the only face to face in class but increases learning time by utilizing cyberspace.

Less active direct learning (conventional) is due to monotonous learning and students are placed as passive learners, which means students get knowledge from the material presented by the teacher during classroom learning. Students accept the subject matter from the teacher and know the concept without understanding the concept correctly. This results in learning that is less meaningful in class and students assume that all material given by the teacher is memorizing. The conventional learning model considers students as individuals who do not have prior knowledge before learning, and the teacher must transfer that knowledge to students regardless of what concepts students already have. The teacher considers what is taught to be able to be accepted by students as a whole does not depend on the initial concepts that exist in students so that misconceptions often occur in students. This strategy has an impact on the learning achievement that is not maximized by students.

The findings of this study have the following implications: First, the average physics learning achievement of students who learn to use MBLBM is different from students who study with MBL or MPK. Thus, the use of learning models in the learning process has a different effect on students' physics learning achievement. The average learning achievement of students who learn to use MBLBM is higher than students who study with MBL or MPK. The relatively high physics learning achievement of students learning to use MBLBM is evident from the strength of problem-based face-toface learning and online learning in helping the construction process of knowledge in students' cognitive structures to be more meaningful.

\section{Conclusion}

Based on the results of testing the hypotheses and the results and discussion described, this study concluded that there were differences in students' physics learning achievement between students who learned using problem-based blended learning models, blended learning models, and conventional X-class science learning models at Denpasar 6 Public High School. ( $F=264.307$, with a significance of 0.001 ) The group of students who learned to use problem-based blended learning models showed that physics learning achievement was relatively higher compared to groups of students who learned using blended learning models even though conventional learning models.

\section{References}

[I] Asiah, I. N., Sudarti, \& Lesmono, A. D. (2016). Pengaruh model problem based learning (PBL) dengan teknik mind mapping terhadap hasil belajar fisika siswa di SMA Negeri Arjasa kelas X. Jurnal Pendidikan Fisika. 4(4): 327-330. Terdapat pada hppts://jurnal.unej.ac.id/.

[2] Soetardjo \& Soejitno, P. O. (1998). Proses belajar mengajar dengan metode pendekatan keterampilan proses. Surabaya: SIC.

[3] Herlina, F., Supriyati, Y., \& Astra, I M. (2015). Pengaruh model pembelajaran berbasis blended learning dan motivasi belajar terhadap hasil belajar fisika siswa SMA. Prosiding Seminar Nasional Fisika (E-Journal). 4: 6I-66. Terdapat pada http://snf-unj.ac.id/.

[4] Supratiwi, N. L. G. F. (2015). Penerapan model blended learning untuk meningkatkan motivasi dan prestasi belajar IPA siswa kelas VIII B SMPN 2 Sawan semester II tahun ajaran 20I4/20I5. Skripsi

[5] Maulidiyahwarti, G., Sumarmi, \& Amirudin A. (2016). Pengaruh model problem based learning berbasis outdoor study terhadap hasil belajar siswa kelas XI IIS SMA. Jurnal Pendidikan: Teori, Penelitian, dan Pengembangan. 
I(2): 94-I00. Terdapat pada https://journal.um.ac.id.

[6] Irawan, V. T., Sutadji, E. \& Widiyanti. (2017). Blended learning based on Schoology: effort of improve learning outcome and practicum chance in vocational high school. Cogent Education. 4(I): I-IO. Doi: I0.1080/233II86X.2017.128203I.

[7] Ceylan, V. K. \& Kesici, A. E. (2017). Effect of blended learning to academic achievement. Journals of Human Science. I4(I): 308-320. Doi: I0.I4687/jhs.vI4iI.4I4I.

[8] Merrit, J., Lee, M. Y., Rilero, P., \& Kinach, B. M. 2017

[9] Nurtanto, M. (2016). Peningkatan motivasi dan prestasi belajar dengan metode problem based learning pada pembelajaran gambar teknik melalui pembelajaran terbimbing. Journal of Mechanical Engineering Education. I(2): 20I-216. Terdapat pada https://jurnal.untirta.ac.id/.
The Influence of Blended Learning Model Based on Problems of....

[10] Aeni, N., Prihatin, T., \& Utanto, Y. (2017). Pengembangan model blended learning berbasis masalah pada mata pelajaran sistem komputer. Innovative Journal of Curriculum and Educational Technology(IJCET). 6(2): 84-97. Terdapat pada https://journal.unnes.ac.id/

[II] Rizkiyah, A. (20I5). Penerapan blended learning untuk meningkatkan hasil belajar siswa pada mata pelajaran ilmu bagunan kelas X TGB SMK Negeri 7 Surabaya. Jurnal Kajian Pendidikan Teknik Bangunan. I(I): 40-49. Terdapat pada http://jurnalmahasiswa.unesa.ac.id/.

[12] Saritepeci, M \& Cakir, H. (2015). The effect of blended learning environments on student's academic achievement and student engagement: a study on social studies course. Education and Science. 40(177): 2013-216. Doi: I0.15390/EB.20I5.2592. 